\title{
POLAND AND JAPAN - THE IMPACT OF THE COLD WAR ON BILATERAL RELATIONS
}

\author{
Ewa Pałasz-Rutkowska \\ http://orcid.org/0000-0002-5819-7032 \\ University of Warsaw
}

\begin{abstract}
Bilateral relations between Poland and Japan were generally friendly since the Russo-Japanese War (1904-1905), throughout the entire interwar era, after the government of Japan recognized independent Poland after WWI (on 6 March 1919), and even during WWII. What was seen as important was a mutual support on the international arena during international conflicts (such as those in Upper Silesia, Manchuria, etc.) and especially military and espionage cooperation. How did the Cold War influence Polish-Japanese relations? Did the relations, which were until that time friendly, play a role in this period - a time of trouble for the entire world? The author tries to answer these questions, relying on selected and important events and issues from the period of the Cold War (until 1989).
\end{abstract}

Keywords: Japan, Poland, mutual relations, foreign policy, diplomatic visits, Cold War, "Solidarity", martial law.

\section{INTRODUCTION}

It is not surprising that geographical conditions, the consequent foreign policy and social moods influenced the relations between Poland and Japan the most throughout the entire history of these countries' bilateral relations, both official and unofficial. ${ }^{1}$ Thus, one of the factors which has brought two such geographically distant countries closer is our mutual neighbor, Russia and its predecessor the USSR. After all, "the

${ }^{1}$ More information on the history of Polish-Japanese relations in: E. Pałasz-Rutkowska, A.T. Romer, Historia stosunków polsko-japońskich, vol. I: 1904-1945, enlarged and revised 3rd edition, Warsaw 2019; E. Pałasz-Rutkowska, Historia stosunków polsko-japońskich, vol. II: 1945-2019, Warszawa 2019.

Address for correspondence: e.palasz-rutkowska@uw.edu.pl 
neighbor of our neighbor (or the enemy of our enemy) is our friend." This element had a very beneficial influence on generally amicable bilateral relations between Poland and Japan. There were of course other factors such as: the lack of direct conflicts, no disputes or wars, and also, what is paramount - the mutual affinity of our two nations. It naturally stemmed from the approach towards Russia but also from certain characteristics shared between our countries: heroism, valor, and dedication to the homeland, compassion for historical tragedies, respect for traditions, relationship with the nature and its influence on the culture (including fascination with Chopin of course), the ties of the individual with the society and the importance of family. The first official Military Attaché to the Diplomatic Mission of Japan in Warsaw (in years 1921-1922), General Yamawaki Masataka (1886-1974), said that:

despite many years of oppression and denationalization during the time of partitions of Poland, Poles managed to preserve their language and culture, which means that the upbringing and the structure of the family are proper. Children respect and obey their parents, as do children back in Japan. ${ }^{2}$

So, our bilateral relations were generally friendly since the Russo-Japanese war, throughout the entire interwar era, after the government of Japan recognized independent Poland after WWI, on 6 March 1919, and even during WWII. What was seen as important was a mutual support on international arena during international conflicts (Upper Silesia, Manchuria, etc.) and especially military and espionage cooperation. The last of which was of special interest to Japan as they did appreciate the abilities of the Polish intelligence officers. Poland was a great strategic spot to gather intelligence, mainly from the East, which meant USSR, but since the end of 1930's, also from the West, which meant Germany (after Germany signed the RibbentropMolotov Pact with the USSR, Japan lost trust in its ally, because the Germans violated the Anti-Comintern Pact). And therefore, after WWII started, Japan kept friendly relations with Poland, allowing the Polish Embassy in Tokyo to operate officially. Japan's attitude changed in October 1941, due to German pressure. In 1940 Japan signed the Axis alliance agreeing to create a new order in Europe and Asia. By that time, after starting the offensive against the USSR, Germany had already occupied the whole of Poland and wanted it to disappear from the map of the world. Bilateral relations were officially broken off on 11 December 1941, three days after Japan engaged in operations in the Pacific, when Poland just like its allies, Great Britain and the USA, declared war on Japan. Even though the espionage cooperation was still ongoing, till the end of WWII ${ }^{3}$.

\footnotetext{
${ }^{2}$ An interview by A.T. Romer (17 April, 1970, Tokyo); for more about Yamawaki's activity in Poland see: E. Pałasz-Rutkowska, A.T. Romer, Historia, pp. 96-100, 149-153.

${ }^{3}$ See e.g.: Ibid., pp. 288-375; E. Pałasz-Rutkowska, A.T. Romer, "Polish-Japanese Co-operation during World War II," Japan Forum 1995, vol. 7, no. 2, pp. 285-317; J.W.M. Chapman, "Japan in Poland's Secret Neighbourhood War," Japan Forum 1995, vol. 7, no. 2, pp. 225-283; E. Pałasz-Rutkowska, "Rescuer of Refugees in Tokyo: Polish Ambassador Tadeusz Romer," Darbai in Dienos 2017, no. 67, pp. 239-254, https://eltalpykla.vdu.lt/handle/1/34412 (access: 12 May 2020).
} 
Japan lost the war and on 15 August 1945 and accepted the unconditional surrender, specified in the Potsdam Declaration. ${ }^{4}$ The occupation by Allied Forces under General Douglas MacArthur (1880-1964) began in September 1945. Post-war Poland, according to decisions made during the Yalta Conference (February 1945), found itself in the zone of Eastern influence, totally dependent on the USSR. Czechoslovakia, Hungary, Romania, Bulgaria, etc. were also in this zone. Soon, the Cold War started and the division between the East and the West, between capitalist and communist factions was becoming deeper both in Europe and Asia. Japan and Poland were on the opposite sides - Japan became an ally to the West and the USA, whereas Poland to the East and the USSR. ${ }^{5}$

How did the Cold War influence Polish-Japanese relations? Did the relations, which were friendly until that time, play a role in this period - a time of trouble for the entire world? I would like to answer these questions basing on selected events and issues from that time (until 1989), which I consider important.

\section{THE RESTORATION OF OFFICIAL RELATIONS AND BEGINNING OF DIPLOMATIC CONTACTS}

In 1948, in order to limit the escalation of the Soviet influence in Europe, the United States gave millions of dollars in economic support of the European states, as part of the so-called Marshall Plan (the European Recovery Program). This aid was also to be targeted at the Eastern Bloc countries, including Poland, but Moscow declined it. In 1949, the West originated two German States, whose area corresponded to the occupation zones: Federal Republic of Germany (American, English and French zone) and the German Democratic Republic (Soviet zone). In 1949, the Council for Mutual Economic Assistance (pol. Rada Wzajemnej Pomocy Gospodarczej) was established, enabling the USSR to utilize the economies of the Eastern Bloc. All areas of life, including culture were subject to the process of Stalinization. Soon, the West established the North Atlantic Treaty Organization (NATO), whose main goal was a military defense against the threat of the USSR and its satellite states (in 1955 the East established the Warsaw Pact). In 1949, China was divided into the People's Republic of China (PRC) and the Republic of China (Taiwan), a similar situation was the case e.g. in Korea and Vietnam.

\footnotetext{
${ }^{4}$ Potsdam Declaration in: „Zbiór dokumentów”, Polski Instytut Spraw Międzynarodowych; hereafter as ZdPISM 1951, no. 9-10, Doc. 129, pp. 1540-1544.

${ }_{5}$ See: E. Pałasz-Rutkowska, "Polska i Japonia po II wojnie światowej. W 60. rocznicę wznowienia stosunków oficjalnych," Prace Historyczne 2017, no. 144/4, pp. 793-809, http://www.ejournals.eu/ Prace-Historyczne/2017/Numer-4/art/10096/ (access: 12 May 2020).
} 
In 1949, Washington decided to change policies towards Tokyo and the so-called Reverse Course was introduced. ${ }^{6}$ Japan was supposed to gradually assume the role of an American ally and due to its geographical location become an anti-communist beachhead during the intensifying Cold War. The US decided to end the occupation. On 8 September 1951, 49 countries signed a Treaty of Peace with Japan in San Francisco. ${ }^{7}$ But the USSR, Poland, and Czechoslovakia did not sign it. A Polish representative to the conference, Vice-minister of Foreign Affairs, Stefan Wierbłowski (19041978) supported the stance of the USSR saying that the meeting was not a conference of sovereign countries and explained that the treaty had gone far towards creating new sources of tension in Asia and contributed to "rebuilding a defeated militarism in the service of American imperialism." ${ }^{8} \mathrm{He}$ also called the exploit of not inviting the PRC to the conference "a shameless act of lawlessness."

The next years did not bring vivid changes in Polish-Japanese relations, although some Polish politicians talked about Japan in positive terms, acknowledging that there were no specific points of conflict between our countries. Greater possibilities for negotiations appeared after the death of Joseph Stalin (1878-1953), as Moscow also changed its negative attitude towards Japan. It all started in April 1954 when the Polish Ministry of Foreign Affairs was granted Moscow's approval for negotiations. ${ }^{9}$ In the USSR Stalin's successor, Nikita Khrushchev (1894-1971) decided to restore bilateral relations with Japan. However, the conclusion of the peace treaty was stifled by the controversies surrounding territorial claims to four islands (Shikotan, Habomai, Etorofu/Iturup, and Kunashiri/Kunashir). Finally, Prime Minister Hatoyama Ichirō (1883-1959) agreed to separate the normalization of bilateral relations from the treaty and territorial disputes. On 19 October 1956, in Moscow, a Joint Declaration (jap. kyōdō sengen) between Japan and the USSR, providing for the end of the state of war and for the restoration of diplomatic relations, was signed. ${ }^{10}$

At the same time, in Poland, the de-Stalinization process started. The forerunner to the changes was The Fifth World Festival of Youth and Students for Peace and Friendship in $1955 .{ }^{11}$ The Festival influenced the changes in the awareness of the Poles, who were also affected by the bloody repression of the protests of workers in

${ }^{6}$ For more information on Japan after WWII see, e.g.: T. Nakamura, A History of Showa Japan, 1926-1989, Tokyo 1998; Shōwa Japan: Political, Economic and Social History, 1926-1989, vol. 2: 1941-1952, ed. S.S. Large, New York 1998; A. Gordon, Nowozytna historia Japonii, transl. I. Merklejn, Warszawa 2010, pp. 334-448; E. Pałasz-Rutkowska, K. Starecka, Japonia, Warszawa 2004, pp. 190-266; J. Polit, Hirohito. Tajemnica cesarza Shōwa 1901-1989, Kraków 2019, pp. 719-890, etc.

7 Treaty of Peace with Japan in: Database of Japanese Politics and International Relations, National Graduate Institute for Policy Studies; Institute for Advanced Studies on Asia, The University of Tokyo, https://worldjpn.grips.ac.jp/documents/texts/docs/19510908.T1E.html (access: 3 March 2019).

${ }^{8}$ ZdPISM 1951, No. 9/10, Doc. 157, pp. 1936-1948.

9 Archiwum MSZ (hereafter as AMSZ), Departament V Wydział III, Japonia 08. Nawiazywanie stosunków dyplomatycznych z Japonia, 1954-1957, collection (c.) 12, bundle (b.) 15, file (f.) 367, p. 2.

${ }^{10}$ ZdPISM 1956, No. 10, Doc. 308, pp. 1584-1591.

${ }^{11}$ A. Krzywicki, Poststalinowski karnawat radości. V Światowy Festiwal Młodzieży i Studentów o Pokój i Przyjaźń, Warszawa 1955 r., Warszawa 2009. 
Poznań in 1956 (Poznań June). Władysław Gomułka (1905-1982) gained power as the First Secretary of the Central Committee of the Polish United Worker's Party. Despite indignation in Moscow and Khrushchev's visit to Warsaw, it was possible to avoid the intervention of the Red Army in Poland. A short period of "thaw" began in Poland, which meant, e.g. some changes in the power apparatus, rehabilitation of political prisoners, etc. Adam Rapacki (1909-1970) became a Minister of Foreign Affairs.

It can be said that since 1955 the issue of regulating Polish-Japanese relations picked up steam. Starting from the same 1955, the gradual build-up of cooperation between Poland and Japan became visible. For example, a delegation of Japanese members of the parliament visited Poland for the first time, a Polish delegation took part in the International Conference to Ban Nuclear Weapons organized in Hiroshima. In 1956, the visit of a delegation of the Committee of International Communications of the Japanese Labor Union of Construction and Lumber Workers launched future contact between Polish and Japanese unionists and the Japan-Poland Society (jap. Nihon Pōrando Kyōkai) was founded in Tokyo. ${ }^{12}$

In these two years, the bilateral talks between Poles and Japanese were continued. The abundant documentation of the Diplomatic Archives of the Ministry of Foreign Affairs in Tokyo shows that both sides wanted to restore official relations. ${ }^{13}$ In June 1956, secret reports were created at the European and American Affairs Bureau (jap. Ōbeikyoku): Waga kuni to Tōō shokoku to no kankei (en. Our Country's Relations with Eastern European Countries) and Tōō shokoku to no kokkō kaifuku mondai ni kansuru keii (en. Details Concerning the Issue of Reestablishing National Relations with Eastern European Countries). ${ }^{14}$ Poland is discussed there in greatest detail, more so than: Czechoslovakia, Romania, Bulgaria, Hungary, Albania and Yugoslavia, which can be considered a proof of the fact that Japan was keen on restoring the relations with Poland quickly, because of the earlier contacts. Poland's role in the Eastern Bloc, was also evident, so the document restoring the official relations with Poland would become model for agreements with other communist states.

The Japanese negotiator, Kase Toshikazu (1903-2004), wrote on 22 October 1956 in a diplomatic cable to Minister of Foreign Affairs Shigemitsu Mamoru (1887-1957) that the Polish side wanted to exchange a declaration ending the state of war without determining the issue of a peace treaty, and exchange diplomats in the rank of ambassador. Poland wanted the document that would restore the relations with Japan to take the form of a "joint declaration" (jap. kyōdo sengen), similarly to the document that

${ }^{12}$ AMSZ, Departament V, Wydział III, Japonia 568, 1956, c. 12, f. 364, b. 15, pp. 1, 2. Its inauguration took place in the Japanese Diet building. The main organizer of the society was Mori Motojirō, then a member of the upper house of the Diet and a correspondent of the Dōmei Press Agency in Poland before the war. The meeting was also attended by Nomizo Masaru, a parliamentarian, who visited Warsaw in 1955, Sakō Itoko, a wife of Shūichi, the first and the last ambassador of Japan to Poland before WWII, Hara Chieko, the first Japanese pianist, who took part in the Chopin Competition in Warsaw (1937).

${ }^{13}$ Gaimushō Gaikō Shiryōkan (Diplomatic Archives of the MOFA, Tokyo; hereafter as GGS), A'1.3.3.5-1, Nihon Pōrandokan gaikō kankei zasshū. Kokkō kaifuku kōshō kankei, part 1, 2.

${ }^{14}$ GGS, A'1.3.3.5-1, part 1, pp. 81-90, 91-94. 
had been signed with the USSR..$^{15}$ Interestingly, in previous documents I found in the Diplomatic Archives of the Ministry of Foreign Affairs of Japan, the term "treaty" (jap. joyaku) was used. ${ }^{16}$ The war reparations were the only contentious question, however, both Poland and Japan, decided to renounce all claims "of the state or its organization or of its citizens which had resulted during the war between the two states." 17

Finally, on 8 February 1957, in New York, the Japanese Ambassador to the United Nations, Kase Toshikazu, and the Polish Deputy Minister of Foreign Affairs, Józef Winiewicz (1905-1984), signed the Agreement Relating to the Restoration of Normal Relations Between the People's Republic of Poland and Japan. ${ }^{18}$

The exchange of ratification documents took place on 18 May 1957 in Warsaw. The Polish side was represented by the Minister Adam Rapacki and the Japanese side - by the Ambassador Extraordinary at Large, Sonoda Sunao (1913-1984). Minister Rapacki expressed the belief that the Agreement marked the beginning of a new chapter in the history of Poland-Japan relations, in which the political, economic and cultural relations would prosper. ${ }^{19}$ Ambassador Sonoda made statements saying that:

Our countries were connected in the past by ties of cordial friendship that were broken during WWII, bringing great harm to both nations ... Our nation and government ... are convinced that our friendship will tighten in the best interests of Japan and Poland ...

Japan can export to Poland considerable amounts of textile materials, copper wire and many other commodities. At the same time, it is possible to import a range of commodities and appliances from Poland ... Japan and Poland are separated by two oceans and the USA on one side, and by China and the Soviet Union on the other. This is why I believe that it would be beneficial for the both sides to sign trilateral trade agreements ... [We] also believe that the mutual exchange of motion pictures, literary works, and also of scientific and technical documentation would benefit both our nations and serve the cause of strengthening the friendship between Poland and Japan. ${ }^{20}$

The agreement was widely described in the press, both in Japan and in Poland. One article from the Yomiuri Shinbun (24 January 1957), entitled Nishükango ni wa chōinka. Nihon Pōrando fukkō. Mondaiten wa shüsen sengen (en. The signing in two weeks? The restoration of relations between Poland and Japan. The issue of the endof-war declaration) is especially interesting. The author of the article stressed the

${ }^{15}$ GGS, Pōrando no kokkō kaifuku mōshiire no ken, pp. 95-97.

${ }^{16}$ For example: ibid., Kokkō kaifuku ni kansuru Nihonkoku Pōrando kan jōyaku (25 January 1955), p. 38.

${ }^{17}$ AMSZ, Departament V, Wydział III, Japonia 08, pp. 15, 18-20.

18 The original in French and a Polish version Układ o przywróceniu normalnych stosunków między Polska Rzeczapospolita Ludowa a Japonia, in: Internetowa baza traktatowa MSZ (Warsaw), Umowy dwustronne, Japonia, doc. 1, https://traktaty.msz.gov.pl/umowa-1 (access: 30 April 2020); in Japanese as Nihonkoku to Pōrando Jinmin Kyōwakoku to no aida no kokkō kaifuku ni kansuru kyōtei in: GGS, A' 1.3.3.5-1, part 2, pp. 19-22.

19 Trybuna Ludu, 19 May 1957, p. 2.

20 ZdPISM 1957, no. 5, dok. 115, pp. 1150-1152. Treaty on Commerce between the Poland and Japan was signed in April 1958, however, the agreement on culture and science would not have been signed for more than a decade. 
importance of the agreement, as it would be the first one signed in the Eastern Bloc in Europe (after the Joint Declaration with the USSR), and thus, it would serve as a model for other such agreements with the remaining members of the Bloc. He believed that calling the document "protocol" (jap. giteisho) could be problematic in the future. As there were no issues of territorial disputes or prisoners of war between Poland and Japan, as was the case with the USSR, the document should be called a "peace treaty" (jap. heiwa joyaku). However, as the author writes, the Polish side requested that the document had the form of a "protocol" and that it contained the same provision about the end of the state of war, as the Joint Declaration with the USSR. The author of the article also mentions, that on 11 December 1941, Poland declared war on Japan, however, the note had not been officially received by the Japanese side. Finally, the term "agreement" (jap. kyōtei) was adopted for the document, and "protocol" was used in the document signed a few days later with Czechoslovakia (13 February 1957). ${ }^{21}$

Soon after the Agreement was signed, both parties embarked on the preparations to open their diplomatic posts in Warsaw and Tokyo. The first Ambassadors became Tadeusz Żebrowski (from November 1957, till 1964) and Ōta Saburō (from January 1958, till 1961). ${ }^{22}$ Both ambassadors did not have an easy task to fulfill. They were working in countries on different sides of adverse political blocks, and still, the ongoing Cold War did not help them. They were obliged to fulfill policies with accordance to their allies - the USSR and the USA. Establishing and organizing posts was not an easy task, but also gaining experience in a new situation, which was different from the pre-war era, when both countries had friendly relations, was difficult. It was especially challenging for Poland, where along with the political framework and government, the diplomatic personnel changed. There were no experts, who knew Japan, its culture and language. While among members of the staff of the Embassy of Japan in Warsaw, three spoke Polish (Dōshō Hisashi, Hashizume Mitsuo, Shunaga Genshirō) and one Poles (Czesław Miszkiewicz), who spoke Japanese helped them. They all worked at the Embassy in Warsaw before the war!

Despite the fact that the beginnings were difficult, the relations between Poland and Japan gradually intensified. In October 1958, a delegation headed by Nagano Shigeo (1900-1984), Adviser to the Minister of Foreign Affairs and General Manager of Fuji Iron \& Steel Co., Ltd. visited Poland to discuss the economic cooperation between the two countries with Trade Minister, Witold Trąmpczyński (1909-1982.)23 In following months, Deputy Minister of Foreign Affairs Takeuchi Shinkichi met with Deputy Minister Winiewicz. A delegation of the National Diet from Japan took part in the 48th Inter-Parliamentary Union Conference in Warsaw (August-September 1959. ${ }^{24}$ In September 1959 Miki Takeo (1907-1988), a member of the ruling Liberal

${ }^{21}$ In the following years Japan resumed relations with: Hungary (August 1959), Bulgaria and Romania (September 1959), German Democratic Republic (May 1973) and Albania (March 1981).

${ }^{22}$ On the beginning of their activities see: E. Pałasz-Rutkowska, Polska i Japonia po II wojnie światowej, pp. 807, 808 and idem, Historia stosunków..., vol. II, pp. 66-86.

${ }_{23}$ AMSZ, Protokół Dyplomatyczny, Japonia 074. Sprawy protokolarne. Wizyty, 1958, c. 16, b. 24, f. 403, pp. $1-3$.

${ }^{24}$ Trybuna Ludu, 27 August 1959. 
Democratic Party (LDP), visited Poland with a delegation, which was the first visit of a high-ranking official of the LDP. ${ }^{25}$

I would like to mention that one of the main tasks of Żebrowski's activity was to discuss the Rapacki Plan, an initiative of Foreign Minister Adam Rapacki, with the aim of creating a nuclear-free zone in Eastern and Central Europe. Kanayama Masahide (1909-1997), the Director General of the European Oceanic Department (jap. $\bar{O} a k y o k u$ ) at the Ministry of Foreign Affairs, told Żebrowski that the plan had limited chances to succeed because of "the great mistrust between the two blocks." ${ }^{26} \mathrm{He}$ avoided providing a straightforward answer, despite the fact that Żebrowski explained that Poland did not want the Federal Republic of Germany to be armed with nuclear missiles. They also discussed Japan's potential neutrality, which was also deliberated on internationally. Kanayama, however, stated that it would not be possible, especially because of Japan's two neighbors: the USSR, which had nuclear weapons and the People's Republic of China which had a vast army. Żebrowski discussed the Rapacki Plan also with Suzuki Mosaburō (1893-1970), the Chairman of the Japan Socialist Party and during a rally on the 5th anniversary of American hydrogen bomb testing at Bikini Atoll, the nuclear fallout from the test contaminated Japanese fishermen. ${ }^{27}$

The official relations between two countries began, but the still ongoing Cold War did not help to facilitate this development, the political and diplomatic relations were not so easy and did develop very slowly. Fortunately, owing to the mutual sympathy between the two nations, which still existed since the beginning of the 20th century, cultural, academic and economic cooperation was developing steadily. It was the economic cooperation that was created. A similar situation can be observed in the field of culture, where despite the East-West division, ruling ideologies became less important. Economy and culture became two areas where the cooperation between the two countries developed better than in other fields. ${ }^{28}$ This was compliant with the policies of both countries from the time when they resumed their relations.

During the subsequent years, Polish and Japanese policy was in accordance with the policy of their main allies, the USSR and the USA. There were, however, some discrepancies. For example, the thaw in Sino-American relations was a surprise for Japan, but also for the USSR (both the USA and the PRC opposed the expansionist policies of the USSR). In 1971 the PRC was admitted to the United Nations which resulted in Taiwan losing its seat in the organization. The PRC became a permanent member of the United Nations Security Council. Consequently, the Japanese

${ }_{25}$ AMSZ, Departament V, Wydział III, Japonia 074. [Spr. przyjazdu do Polski Takeo Miki], 1959, c. 12 , b. 39 , f. 953 .

${ }^{26}$ Ibid., Japonia 086. Notatki z rozmów, 1959, c. 12, b. 39, f. 955, p. 4; in 1967-1968 Kanayama served as Ambassador to Poland.

${ }^{27}$ Ibid., pp. 10-12.

${ }^{28}$ For more details see: E. Pałasz-Rutkowska, Historia stosunków, vol. II, pp. 162-192, 424438; Z. Osiński, Polskie kontakty teatralne z Orientem w XX wieku, vol. I: Kronika, Gdańsk 2008, pp. 150-227 (excerpts about Japan); A. Tarnowski, Polska i Japonia 1989-2004. Stosunki polityczne, gospodarcze i kulturalne, Warszawa 2009, pp. 15-31. 
government needed to revise its policy towards the PRC, and finally, in September 1972, normalized its relations with the PRC and suspended relations with Taiwan. Before that, Ambassador to Japan, Zdzisław Regulski (in years: 1972-1975) wrote to the Ministry of Foreign Affairs in Warsaw (19 July 1972) that the Japanese government intended to liberalize relations with socialist states but only after the difficult "Chinese question" was solved. ${ }^{29}$ Japan was to "maintain possibly identical principles with regard to all communist states, including Cuba." ${ }^{30}$

Interestingly enough, that in this context, in 1979 Ambassador Stefan Perkowicz (in years 1976-1980) wrote in his report, that because of the change in the situation in East Asia, mainly, due to the new relations between Japan and the PRC, as well as the PRC and the USA, the role of the Polish diplomatic mission in Tokyo as "an observation point regarding policies and cooperation of Japan, the USA and China towards the USSR and soviet states" increased. ${ }^{31}$ Thus, the strategic spot to gather information was moved from Warsaw (so important for Japan in the interwar period and during WWII) to Tokyo.

During that period, Japan caught up with the world's most developed countries and became the third country, after the USA and the USSR, with the highest gross domestic product (among others, thanks to American spending in Japan during the Vietnam War). And after another decade, it would outstrip the USSR. At the beginning of the 1970's, Poland was also undergoing a "specific" economic growth caused by the policies of the new First Secretary of the Central Committee of the Polish United Workers' Party, Edward Gierek (1913-2001), who succeeded Władysław Gomułka in 1970, after his resignation from the office as a result of the increasing financial crisis, growing social discontent and subsequent protests. The so-called Gierek Decade was characterized by a higher degree of "openness" to the West, and some politicians around the world, also in Japan, believed that Poland was becoming a model European country. ${ }^{32}$ This fact was mentioned in the reports from the Polish Embassy in Tokyo to the Polish Ministry of Foreign Affairs. In Japan the attitude towards Poland and Poles was "marked by particular expressions of friendship", which was generally influenced by Polish history, with which the Japanese were familiar, and "the economic success together with the modernization of the Polish industry achieved after 1970." ${ }^{\prime 3}$

The cooperation was developing rapidly, and official visits became more regular as well, especially those connected to trade, e.g. trade missions of the Keidanren (jap. Nippon Keizai Dantai Rengōkai; en. Japan Federation of Economic Organizations), numerous companies, e.g. Mitsubishi, Mitsui, Marubeni, Sumitomo. ${ }^{34}$ In 1971

${ }^{29}$ AMSZ, Departament II, Księga nabytków i ubytków (hereafter as Nabytki), Japonia 1972 (24/76, b. 3), D. II. Jap-0-22-1-72 Polska - Japonia. Stosunki dwustronne (plik depesz).

${ }^{30}$ Ibid.

${ }_{31}$ AMSZ, Nabytki, Japonia 1980 (28/85 b. 4) D.II.Jap-023-1-80, Plan pracy.

32 Z. Rurarz, Bytem doradca Gierka, Chicago-Toronto-Warszawa 1990.

${ }_{33}$ AMSZ, Nabytki, Japonia 1978 (5/84, b. 3), D. II. Jap-242-1-78 Raport polityczny Ambasady PRL w Tokio z 1977 rok.

${ }^{34}$ Ibid., Japonia 1973 (8/77, b. 3), D. II. Jap.23-8-73, Japońska misja gospodarcza - Toshio Doko. 
Kanbara Katsuyuki (1941-2015) came to Poland as the official representative of the Nichimen Corporation. ${ }^{35} \mathrm{He}$ was the first person from Japan in Poland to coordinate the import of Polish coal. He operated in Poland (with breaks in 1977-1984, 19881991) for almost forty years, until the end of his days. So, he became a specialist and advisor on Polish-Japanese economic cooperation and investment issues.

Also, the subsequent events can attest to the development of the trade relations: in 1972 the Japan - Poland Trade Commission (jap. Nihon Pōrando Keizai Iinkai), with Dokō Toshio (1896-1988; the president and later chairman of Toshiba Corporation) as the Chair was created at the International Chamber of Commerce in Tokyo and then an analogous Poland - Japan Trade Commission was created at the Polish Foreign Trade Chamber in Warsaw. In May 1975, Japan External Trade Organization (JETRO; jap. Nippon Bōeki Shinkō Kikō) opened its office in Warsaw. At that time, Poland became the fourth country in the Eastern Bloc in terms of trade relations with Japan, after the USSR, the PRC and Cuba. ${ }^{36}$

The visit of the Prime Minister Piotr Jaroszewicz (1909-1992) to Japan in September 1978 proved important. ${ }^{37}$ There were plans for the visit of the First Secretary Edward Gierek, but they did not come to fruition. During Prime Minister's visit numerous important documents were signed: the new trade and maritime agreement, the scientific and technological cooperation agreement, what is more, notes about cultural cooperation were exchanged..$^{38}$

During the reception in honor of the guest, Prime Minister Fukuda Takeo (19051995) said:

Despite considerable geographical distance between the two nations, we share a profound tradition of relations of friendship basing on mutual respect and understanding for the culture and tradition of the two nations ... Your national character is marked by talent and passion, Your art and culture is inspired by these national qualities - all this commands our respect and perpetual admiration for Your country.

The next day he also said (causing some confusion):

I heard that in Your country there is a saying "Poland and Japan are two neighboring countries separated by a large forest". Indeed, we are geographically separated by a "large forest" and we also differ in the form of government in our countries. Nevertheless, I am truly convinced that what is most important for further development and strengthening of good neighborly relations

${ }^{35}$ Based on the conversation with Kanbara Midori (6 February 2019, Warsaw) and the website of Związek Pracodawców Shokokai http://www.shokokai.pl/mr-kambara-honorary-advisory.html (access: 10 July 2018).

${ }^{36}$ AMSZ, Nabytki, Japonia 1970 (46/75, b. 2), Jap. 0-242-2-70, Rap. polit.-ekonomicz., lipiec 1969 kwiecień 1970.

${ }^{37}$ The number of documents in both Polish and Japanese archives proves it, see e.g.: ibid., Japonia 1978 (6/84, w. 3), D. II. Jap.220-3-78, Wizyta w Japonii prezesa Rady Ministrów tow. Piotra Jaroszewicza od 15 do 19 listopada 1978; GGS, SA.1.3.2-2011-0778, Yaroshevitchi Pōrando shūshō fusai hōnichi, and others. See also E. Pałasz-Rutkow ska, Historia, vol. II, pp. 173-180.

${ }^{38}$ Internetowa baza traktatowa MSZ, Umowy dwustronne, doc. 2 and 3, https://traktaty.msz.gov.p1/ umowa-1 (access: 30 April 2020). 
between our two countries in need of one another is the fact that we share the common desire for good relations of interdependence and the desire for peace. ${ }^{39}$

But the economic situation in Poland deteriorated rapidly. The repayment of interests on foreign loans exceeded the state's payment capacity. External debt was increasing, as was the trade deficit. Export was increased and supply on the domestic market was limited. This resulted in the enactment of the rationing system, price increases, and consequently, mass protests and walkouts. Gierek was forced to resign. Eventually in 1981, the Independent Self-Governing Trade Union "Solidarity" was formed with Lech Wałęsa (born 1943) as the leader. The government agreed to reforms. Soon afterwards, the "Solidarity" delegation arrived in Japan (10-17 May 1981 ) in order to establish contacts with Japanese union members, mainly with the General Council of Trade Unions of Japan, Sōhyō (jap. Nihon Rōdō Kumiai Sōhyō Gikai). ${ }^{40}$ A few months later in September, Tomizuka Mitsuo (1929-2016), the Secretary General of Sōhyō, was guest at the First Congress of "Solidarity" in Gdańsk. Wałęsa became very popular in Japan and the visit brought two nations closer. In Japan, it was the time of an increased interest in Poland. ${ }^{41}$ During my research, I found out that from January 1980 to December 1981, the newspaper Asahi Shinbun published a total of 2008 articles and mentions about Poland, and the Yomiuri Shinbun1188. It is also confirmed that many Japanese journalists visited Poland during those two years.

In 2011 Shiraishi Kazuko, the Minister-Counsellor in the Embassy of Japan in Warsaw at that time, who at the time worked at the "Polish Desk" in the Ministry of Foreign Affairs in Tokyo and spent many years in Poland, told me that:

Japan was highly interested in what was happening in Poland in August 1980. However, we were afraid that things would not end well, just as previously in 1968, 1970 or 1976. ... Japan's role, as one of the Western countries, was to support the aspirations of Polish people, so that these [democratic] objectives would be fulfilled.

And indeed, the increasing pressure from Moscow to solve this situation "dangerous" to the Eastern Bloc forced Polish authorities to begin a crack-down on "Solidarity". The arrests of the members began, and in the morning of 13 December 1981, General Wojciech Jaruzelski (1923-2014) declared martial law in Poland. This worsened the economic situation in Poland even further, the Paris Club started the treatment of Poland's external debt, and Western countries imposed economic sanctions on the People's Republic of Poland.

\footnotetext{
${ }^{39}$ GGS, SA.1.3.2-2011-0778 and private archive of the author.

${ }^{40}$ For details see, e.g.: AMSZ, Nabytki, Japonia 1981 (39/86 w. 2), D. II. Jap.0-22-2- 81, Wizyta delegacji „Solidarności” w Japonii; see also: A. Nasiłowska, Wolny agent Umeda i druga Japonia, Warszawa 2013, pp. 272-284; Asahi Shinbun, 10-18 May 1981.

${ }^{41}$ At the same time, after the Soviet army started the war in Afghanistan (December 1979), Japan boycotted the 1980 Summer Olympics in Moscow and imposed sanctions against the USSR.
} 
On 23 December 1981, a Polish Ambassador in Japan, Zdzisław Rurarz (in 1981), asked for political asylum at the Embassy of the United States in Tokyo. ${ }^{42}$ This, of course, had its repercussions in Warsaw. Japanese Ambassador Hara Fujio (in years 1980-1983), answered allegations of the Polish Ministry of Foreign Affair that Japanese authorities "facilitated" Rurarz's desertion by saying that he was not aware of any such "facilitation" in the escape and that it customary that "upon request of the Embassy of the United States of America ... Tokyo police only provided protection for Rurarz until he left Japan." 43

Not long after, the First Secretary of Japanese Embassy, Military Attaché, Colonel Morita Tadanobu, visited the Polish General Staff, and during that visit he said:

Japan has close ties with Poland ... and believes the further fulfillment of the obligations stipulated by the bilateral agreements is dependent on the transparency of the political and economic situation in Poland and on the development of the situation. Some countries postulate that Poland should be subject to political and economic boycott. Japan does not wish to subjugate its economic interest to the external pressures but would like to formulate the principles of further policy towards Poland basing on the objective view of the reality. ${ }^{44}$

In February 1982, Ambassador Hara deposited the original copy of the letter written on 16 January 1982 by Prime Minister of Japan Suzuki Zenkō (1911-2004) at the Ministry of Foreign Affairs in Warsaw. This was the answer to the letter from Jaruzelski (from 5 January 1982) in which the general explained the reasons for the declaration of the martial law, and also expressed his hopes that this decision would be accepted and that "the strengthening of the kind interest in changes of the political life in Poland" would be possible. ${ }^{45}$ Suzuki replied that he believes that the talks which would "put an end to the abnormal situation in Poland and establish the true national harmony" would be held soon. He also stated that he will make effort in order to recognize various Japanese economic obligations towards Poland, and:

If the expectations are fulfilled, the cooperation between our countries ... will be strengthened henceforth. Otherwise, we will be forced to revise the current relations with your country ... I believe that the current state of affairs in Poland is the result of pressures from the Soviet Union.

On numerous occasions the Japanese side emphasized that "Japan shares the common opinion of the West concerning the USSR's responsibility" for the situation in Poland. ${ }^{46}$ On 23 February 1982, Chief Cabinet Secretary, Miyazawa Kiichi

${ }^{42}$ AMSZ, Nabytki, Japonia 1981 (39/86 w. 2), D. II. Jap-0-22-3-81, Dezercja b. amb. PRL w Japonii - Z. Rurarza and Japonia 1982 (42/86 w. 4), D. II. Jap.6-1-82, Inf. dot. Zdzistawa Rurarza; see also: Asahi Shinbun, Yomiuri Shinbun, 25 December 1981.

${ }_{43}$ AMSZ, Nabytki, Japonia 1982 (42/86, w. 4), D. II. Jap-22-10-82, Pilne notatki z rozmów z amb. Japonii p. F. Hara.

${ }_{44}$ Ibid., Japonia 1981 (39/86, w. 2), D. II. Jap-21-1-81, Wizyta attaché wojsk. Japonii ptk. T. Morita w Oddz. Wojsk. Spraw Sztabu Gen. W.P. w dniu 29.12.1981 r.

${ }^{45}$ Both documents in: ibid., Japonia 1982 (42/86, w. 4), D. II. Jap-22-3-82, List premiera PRL tow. gen. W. Jaruzelskiego do premiera Japonii, Zenko Suzuki.

${ }^{46}$ See eg. a document (19 January 1982) in: AMSZ, Nabytki, Japonia 1982 (42/86, w. 4), D.II.Jap22-3-82 List premiera PRL tow. gen. W. Jaruzelskiego do premiera Japonii, Zenko Suzuki. 
(1919-2007), published a statement, saying that suitable measures towards Poland would be taken. ${ }^{47}$. Although the United States and other Western countries imposed sanctions on Poland, the Japanese government did not introduce them and only suspended talks on postponing debt repayment. Furthermore, the travel of the employees of the Polish Embassy within Japan was restricted. Japan still provided the economic aid which had been pledged earlier (August 1981) and whose aim was to stabilize the situation in Poland (e.g. shipments of rice - 20,000 tons of rice for USD 8.7 million) and as humanitarian aid for the Polish nation for food and clothing for the elderly and for medical equipment donated USD 500,000 through the International Red Cross. ${ }^{48}$

The Japanese side explained, that Miyazawa's statement was not intended at meddling in internal Polish affairs, as Japan was only interested in them in the context of international relations and trade interests and that it was not opposing the martial law, provided that it brought positive results and would be lifted soon. Japan also emphasized that the statement was balanced and did not include the word "sanctions" or any demands, and moreover, the resolutions of previous bilateral agreements were realized.

Many Japanese sympathized with Poles and "Solidarity" at that time. A number of members of the Diet founded the All Party Parliamentary Poland Support Group (jap. Pōrando Mondai o Kangaeru Giin Renmei). Labor union members, including Sōhyō organized protests in support of Poland and collected money and necessary items for Poles, various groups also protested in front of the Polish Embassy in Tokyo. The Center for Information on Poland (jap. Pōrando Shiryō Sentā) was opened in Tokyo. ${ }^{49}$ One of its founders was Kudō Yukio (1925-2008), a translator of Polish literature (Bruno Schulz, Witold Gombrowicz, Isaac Singer, etc.), a journalist and a former Japanese language lecturer at the Department of Japanese Studies at the University of Warsaw. He spent seven years in Poland (1967-1974), and already at that time, was involved with the opposition. ${ }^{50}$ Many intellectuals, scientists, and journalists cooperated with him, e.g.: Itō Takayuki (historian, expert on Polish history), Kimura Hiroshi (specialist on Russia), Maeno Ryō (political scientist), Takenami Shōichrō (economist), Ishikawa Hideo (journalist), Kusakabe Kyūshirō (film critic), Senda Akihiko (theater critic and journalist from „Asahi Shinbun”), Tetsuya Chikushi (journalist from „Asahi Shinbun” and TV Asahi), and many others. The main aim of the Center was to collect and publish various materials on the situation in Poland, and therefore, it published (from 1981 till 1991) a monthly called Pōrando Geppō. Poland Monthly. Biuletyn Polski. It provided insight on current events in Poland, on Polish history, politics, economy and culture, on the situation of "Solidarity" and activities of its members. It also included interviews with these people and

${ }^{47}$ Pōrando jōsei ni kansuru Miyazawa Kiichi kanbō chōkan no danwa [in:] Nihon gaikō shuyō bunsho, nenpyō. Japan's Foreign Relations - Basic Documents, ed. Kajima Heiwa Kenkyūjo, vol. 4, Tōkyō 1995, p. 618.

${ }_{48}$ A. Tarnowski, Polska i Japonia, pp. 24-25.

49 Pōrando Geppō. Poland Monthly. Biuletyn Polski, 1 November 1981; Pōrando Geppō, August 1991, no. 112, pp. 3, 4; also based on conversations with A. Żuławska-Umeda.

${ }^{50}$ See: Y. Kudō, Warushawa no shichinen, Tōkyō 1977. 
translations of their texts (e.g. Jacek Kuroń, Adam Michnik, Jan Józef Lipski, Jan Lityński, Lech Wałęsa, Andrzej Wajda). In addition, the Center organized seminars and lectures, film screenings, sent specialists to Poland, invited guests from Poland. Ongoing contacts with "Solidarity" activists were also maintained.

During the martial law, and also later, until 1991, Poles were aided by the Brother Zeno Association for Aid and Relief to Poles (jap. Zeno Shūdōshi Kinen Pōrandojin o Tasukerukai), an organization founded in 1982 by Kudō's wife, Umeda-Kudō Hisayo (1922? 1923-2015). ${ }^{51}$ Japanese trade union representatives, many volunteers, including Polish women living in Tokyo cooperated with Umeda-Kudō. Tasukerukai quickly raised around USD 200,000. The majority of the collected funds were allocated to medicine and food that was sent to Poland, where they were distributed, by opposition activists, to the people who were most in need.

In 1982 Nakasone Yasuhiro (1918-2019) became the Prime Minister and Abe Shintarō (1924-1991) was appointed the Minister of Foreign Affairs. The Prime Minister strived to increase the role of Japan on the international arena, which also meant closer contacts with Eastern European states. The martial law in Poland ended on 22 July 1983, however, the Japanese adopted the wait-and-see attitude and finally in 1984 agreed that the government is ready to strengthen the relations with Poland, under the condition that "the subsequent development of Polish internal situation will be favorable." ${ }^{52}$

The visit of the Minister of Foreign Affairs, Abe Shintarō, in Poland (May 1985) was a proof of the thaw in the relations with Japan. The aim of the visit was explained as follows:

The Japanese side regards the visit, which was initiated by Tokyo, as a sign of the normalization of the bilateral relations and also as proof of contribution of the Japanese policy to the revival of the cooperation between the countries with differing socioeconomic system. Poland ... traditionally enjoys a good reputation in Japan and draws the attention of the economic circles in Japan. ${ }^{53}$

A year later, Polish Minister of Foreign Affairs Marian Orzechowski (born 1931) arrived in Japan on a return visit and in January 1987 Prime Minister Nakasone visited Poland. ${ }^{54}$ It was the first time a Japanese Prime Minister visited Poland in the entire history of Polish-Japanese relations. Since in the same year the USA and other countries lifted sanctions and later the Paris Club reached a decision concerning the repayment of the Polish debt and postponed it, the Japanese government

${ }^{51}$ On the base of conversations with A. Żuławska-Umeda; see also: Yomiuri Shinbun, 4 May 1983.

${ }^{52}$ AMSZ, Nabytki, Japonia 1984 (29/87, w. 2), D. II. Jap-0-22-1-84, Stosunki dwustronne PRL - Japonia; see also: GGS, SA. 1.2.2-2015-1532, Nichi-Pōrando gaikō, part 8.

53 AMSZ, Nabytki, Japonia 1985 (25/88, w. 5), D.II.Jap.220-1-85, Wizyta w Polsce ministra spraw zagranicznych Japonii Shintaro Abe 10-11 czerwca 1985 r. About the visit see also: Asahi Shinbun, 3, 11, 12, 13 June 1985; Yomiuri Shinbun, 11, 12 June 1985; Trybuna Ludu, 10, 11, 12 June 1985.

${ }^{54}$ Details in: AMSZ, Nabytki, Japonia 1987 (26/90, w. 2), D.II.Jap.0-220-1-87, Not. inf. z wizyty ofic. w Polsce premiera Japonii Yasuhiro Nakasone /15-16 stycznia 1987 r. See also: Asahi Shinbun and Yomiuri Shinbun, 16, 17, 18 January 1987; Życie Warszawy, 16 January 1987. 
decided that two further agreements on debt restructuring can be signed with the Polish government. ${ }^{55}$ However, the fourth agreement was not singed (1988) because of unreasonable demands of the Polish side. The Japanese side did not agree to more loans and government guarantees for investments in Poland. Despite the fact that the Ministry of Foreign Affairs in Tokyo reassured Ambassador Ryszard Frąckiewicz (in years 1987-1990) about the "mutual historical and cultural affinities" it was also implied that "neither sentiments nor policy will lead to investments in Poland without rebuilding the trust." 56

Half a year later the Chairman of the Polish Council of State, Wojciech Jaruzelski, came to Japan. On this occasion, Nakasone said during the reception:

Japan and Poland lie far away from each other. However, if one would look into the depths of history, it is clear that a mutual interest existed between our two countries ... The masterpieces of Polish culture and art are well respected in Japan. The history of heroic battles for Poland's independence and freedom is also well-known in Japan ... Is it not possible for these two nations, which boast long cultural traditions, which are characterized by a deep love of their homeland, by the same unwavering spirit which can withstand all the difficulties, to strengthen the ties of friendship? ${ }^{57}$

\section{CONCLUSIONS}

These ties of friendship would be tightened (carefully at first), staring from 1989, when Poland entered the path of democratic reforms and the division of the world into the West and the East started to disappear. During the entire Cold War period our bilateral relations were greatly influenced by the USSR and the USA, the main allies of Poland and Japan standing at the helm of the two opposing, ideologically different blocs. However, as my research shows, regardless of this overwhelming influence, in bilateral relations, Poland and Japan abandoned the ideological hostilities, invoking "traditionally friendly" earlier (prewar) contacts. On many an occasion, the "affinity" of both nations was mentioned and this was proved true at that time, e.g. during the 1964 Summer Olympics in Tokyo. Polish athletes were very successful in the Games and this increased the popularity of Japan and Japanese culture in Poland. The humanitarian aid provided by Japan during the martial law was an exceptional proof of the affinity of the Japanese towards Polish. I myself, have also experienced this affinity many times, but also in the fall of 1983, when I traveled to Japan for a scholarship for the first time. Already at the Narita Airport, the passport control officer congratulated me, as a Pole, on the Nobel Peace Prize awarded to Lech Wałęsa. And Wałęsa

${ }_{55}$ A. Tarnowski, Polska i Japonia, pp. 26-32, 90-92.

${ }_{56}$ AMSZ, Nabytki, Japonia 1989 (3/94), Jap.0-22-1-89, Stosunki dwustronne.

57 AMSZ, Nabytki, Japonia 1987 (26/90, w. 2), D. II. Jap.0-220-2-87, Wizyta w Japonii przewodniczacego Rady Państwa RP ob. W. Jaruzelskiego 29 VI- 2 VII 1987 r. About the visit see also: Asahi Shinbun and Yomiuri Shinbun, 26, 28, 29, 30 June, 1, 3 July 1987. 
joined Frederick Chopin, Nicolaus Copernicus and Marie Skłodowska-Curie as one of the best-recognized Poles in Japan.

\section{BIBLIOGRAPHY}

\section{Unpublished Sources}

Archiwum Ministerstwa Spraw Zagranicznych (abbr. AMSZ), Warsaw.

Gaimushō Gaikō Shiryōkan (Diplomatic Archives of MOFA; abbr. GGS), Tokyo.

\section{Published Sources}

Database of Japanese Politics and International Relations, National Graduate Institute for Policy Studies, Institute for Advanced Studies on Asia, The University of Tokyo, https:// worldjpn.grips.ac.jp/documents/texts/docs/19510908.T1E.html (access: 3 March 2019).

Internetowa baza traktatowa MSZ (Warsaw), Umowy dwustronne, Japonia, https://traktaty. msz.gov.pl/umowa-1 (access: 30 April 2020).

Nihon gaikō shuyō bunsho, nenpyō. Japan’s Foreign Relations - Basic Documents, ed. Kajima Heiwa Kenkyūjo, vol. 4, Tōkyō 1995.

„Zbiór dokumentów”, Polski Instytut Spraw Międzynarodowych (abbr. ZdPISM) 1951, no. $9-10 ; 1956$, no. $10 ; 1957$, no. 5 .

\section{Studies}

Chapman J.W.M., "Japan in Poland's Secret Neighbourhood War," Japan Forum 1995, vol. 7, no. 2, pp. 225-283.

Gordon A., Nowożytna historia Japonii, transl. I. Merklejn, Warszawa 2010.

Krzywicki A., Poststalinowski karnawał radości. V Światowy Festiwal Młodzieży i Studentów o Pokój i Przyjaźń, Warszawa 1955 r., Warszawa 2009.

Kudō Y., Warushawa no shichinen, Tōkyō 1977.

Nakamura T., A History of Showa Japan, 1926-1989, Tokyo 1998.

Nasiłow ska A., Wolny agent Umeda i druga Japonia, Warszawa 2013.

Osiński Z., Polskie kontakty teatralne z Orientem $w$ XX wieku, vol. I: Kronika, Gdańsk 2008.

Pałasz-Rutkowska E., Historia stosunków polsko-japońskich, vol. II: 1945-2019, Warszawa 2019.

Pałasz-Rutkowska E., "Polska i Japonia po II wojnie światowej. W 60. Rocznicę wznowienia stosunków oficjalnych," Prace Historyczne 2017, no. 144/4, pp. 793-809, http:// www.ejournals.eu/Prace-Historyczne/2017/Numer-4/art/10096/ (access: 12 May 2020).

Pałasz-Rutkowska E., "Rescuer of refugees in Tokyo: Polish Ambassador Tadeusz Romer," Darbai in Dienos 2017, no. 67, pp. 239-254, https://eltalpykla.vdu.lt/handle/1/34412 (access: 12 May 2020). 
Pałasz-Rutkowska E., Romer A.T., Historia stosunków polsko-japońskich, vol. I: 19041945, enlarged and revised 3rd edition, Warsaw 2019.

Pałasz-Rutkow ska E., Romer A.T., "Polish-Japanese Co-operation during World War II," Japan Forum 1995, vol. 7, no. 2, pp. 285-317.

Pałasz-Rutkowska E., Starecka K., Japonia, Warszawa 2004.

Polit J., Hirohito. Tajemnica cesarza Shōwa 1901-1989, Kraków 2019.

Rurarz Z., Byłem doradca Gierka, Chicago-Toronto-Warszawa 1990.

Shōwa Japan: Political, Economic and Social History, 1926-1989, vol. 2 (1941-1952), ed. S.S. Large, New York 1998.

Tarnowski A., Polska i Japonia 1989-2004. Stosunki polityczne, gospodarcze i kulturalne, Warszawa 2009.

\section{Newspapers}

Asahi Shinbun

Pōrando Geppō. Poland Monthly. Biuletyn Polski

Trybuna Ludu

Yomiuri Shinbun

Życie Warszawy

\section{Interviews}

with: Kanbara Midori, 2019, Warsaw; Shiraishi Kazuko, 2011, Warsaw; Yamawaki Masataka, 1970, Tokyo (by Romer A.T.); Żuławska-Umeda A., 2019, Warsaw.

\section{Websites}

Związek Pracodawców Shokokai http://www.shokokai.pl/mr-kambara-honorary-advisory. html (access: 10 July 2018). 